ISSN : 2337-3067

E-Jurnal Ekonomi dan Bisnis Universitas Udayana 7.6 (2018): 1565-1588

\title{
NIAT KONSUMEN MEMBELI ULANG PRODUK MEWAH SMARTPHONE
}

\author{
Claudia Lorenzia Core ${ }^{1}$ \\ Ni Wayan Sri Suprapti ${ }^{2}$ \\ ${ }^{1,2}$ Fakultas Ekonomi dan Bisnis Universitas Udayana, Bali, Indonesia \\ 1e-mail: audeyclaudia@gmail.com
}

\begin{abstract}
ABSTRAK
Penelitian ini bertujuan untuk menguji faktor-faktor yang mempengaruhi niat konsumen kota Denpasar membeli ulang produk smartphone merek iPhone, yaitu inersia konsumen, nilai mewah, atribut produk, kepuasan pelanggan dan aspek sosial. Penelitian ini juga menguji efek mediasi kepuasan pelanggan terhadap hubungan antara atribut produk dan niat beli ulang, serta peran moderator aspek sosial terhadap hubungan antara inersia konsumen dan niat beli ulang. Responden yang berpartisipasi dalam penelitian ini sebanyak 154 orang yang memenuhi kriteria sampel yaitu berdomisili di kota Denpasar, sudah lulus SMA dan sedang menggunakan smartphone merek iPhone. Hasil penelitian menunjukkan bahwa inersia konsumen tidak berpengaruh pada niat beli ulang. Selanjutnya ditemukan bahwa atribut produk merupakan pendorong utama kepuasan pelanggan dan niat beli ulang. Kepuasan pelanggan juga ditemukan memediasi hubungan antara atribut produk dan niat beli ulang. Selain atribut produk, nilai mewah ditemukan mampu mendorong niat beli ulang serta aspek sosial memperkuat hubungan antara inersia konsumen dan niat beli ulang.
\end{abstract}

Kata kunci: Niat Beli Ulang, Inersia Konsumen, Atribut Produk, Kepuasan, Aspek Sosial

\section{ABSTRACT}

This study aims to examine the factors that influence the intention of Denpasar city consumers to repurchase the iPhone brand smartphone products, namely consumer inertia, luxury value, product attributes, customer satisfaction and social aspects. The study also tested the effect of customer satisfaction mediation on the relationship between product attributes and re-purchase intentions, as well as the role of moderator of social aspects of the relationship between consumer inertia and repurchase intentions. Respondents who participated in this study as many as 154 people who meet the sample criteria that are domiciled in Denpasar city, have graduated high school and are using smartphone brand iPhone. The results showed that consumer inertia has no effect on repurchase intention. It was further discovered that product attributes were a key driver of customer satisfaction and repurchase intentions. Customer satisfaction is also found to mediate the relationship between product attributes and repurchase intentions. In addition to product attributes, the luxury value found to be able to encourage repurchase intention as well as social aspects strengthens the relationship between consumer inertia and repurchase intentions.

Keywords: Repeat Purchase Intention, Consumer Inertia, Product Attribute, Satisfaction, Social Influence 


\section{Claudia Lorenzia Core, dan Ni Wayan Sri Suprapti. Niat Konsumen Membeli...}

\section{PENDAHULUAN}

Pesatnya perkembangan teknologi informasi telah diikuti oleh semakin meningkatnya produksi smartphone. Smartphone merupakan ponsel yang dibekali dengan berbagai macam fitur serta spesifikasi yang mumpuni dan juga berperan penting dalam banyak aspek dalam kehidupan manusia. Fitur-fitur dan spesifikasi tersebut dibuat untuk memenuhi berbagai kebutuhan konsumen sehingga konsumen dapat merasakan banyak manfaat dalam membantu menyelesaikan pekerjaannya.

Jumlah penduduk Indonesia yang mencapai 250 juta jiwa adalah pasar yang besar. Pengguna smartphone Indonesia juga bertumbuh dengan pesat. Di pasar Indonesia, banyak merek smartphone yang beredar. Apple menjadi salah satu merek yang semakin hari semakin meningkat penjualannya (http://databoks.katadata.co.id/datapublish/2016/08/16/penjualan-smartphone-apple-

2009-2015; diakses tanggal 18 Maret 2017). Produk-produk Apple sendiri tentu sudah tidak asing lagi di kalangan masyarakat dunia, termasuk Indonesia. Variasi lini produk yang dimiliki Apple tentu saja memudahkan konsumen memilih jenis produk mana yang akan dibeli sesuai dengan kebutuhan. Hal ini juga memberikan keuntungan bagi penjualan produk Apple karena keterkaitan produk satu dengan yang lainnya akan membuat konsumen tidak hanya membeli satu produk saja, melainkan membeli produk Apple lainnya untuk menunjang kinerja smartphone yang sudah mereka miliki.

Sebagai produk andalan Apple, iPhone berhasil menjadi raja smartphone dunia setelah mengalahkan penjualan Samsung pada triwulan IV 2016. Penjualan iPhone ke seluruh penjuru dunia pada triwulan IV 2016 mencapai 78,3 juta unit naik 4,7 persen 
dari periode yang sama 2015. Jika dibandingkan dengan triwulan sebelumnya, $\begin{array}{llll}\text { penjualan } & \text { iPhone } & & \\ \text { melonjak } & & \end{array}$ (http://databoks.katadata.co.id/datapublish/2016/10/10/penjualan-telepon-pintarsamsung-vs-apple-inc; diakses tanggal 18 Maret 2017).

Walaupun angka penjualan iPhone secara global di akhir tahun 2016 lebih tinggi dari pesaingnya Samsung, merek smartphone yang menjadi pilihan masyarakat Indonesia masih tetap Samsung. Hal ini dibuktikan dengan hasil riset databoks yang menunjukkan sebanyak $25.42 \%$ masyarakat Indonesia menyatakan Samsung sebagai merek smartphone pilihannya sedangkan smartphone keluaran Apple hanya dipilih $\begin{array}{llll}\text { sebanyak } & 17.7 \% & \text { masyarakat } & \text { Indonesia. }\end{array}$ (http://databoks.katadata.co.id/datapublish/2017/02/02/samsung-dan-apple-pilihantelepon-pintar-masyarakat-indonesia; diakses tanggal 18 Maret 2017).

Namun hal berbeda ditunjukkan ketika bicara tentang merek secara keseluruhan, bukan hanya merek smartphone. Berdasarkan data yang di dapat dari website databoks, merek Apple memiliki nilai yang lebih tinggi dibandingkan merek pesaingnya yaitu Samsung. Merek Apple sendiri dianggap punya nilai tertentu bagi pengguna setianya. Hal ini dikarenakan pengguna produk iPhone atau produk keluaran Apple lainnya tidak sekedar membeli sebuah perangkat smartphone tapi juga membeli gaya hidup, desain artistik, aplikasi dan fitur-fitur lainnya yang mumpuni.

Merek-merek produk yang menyasar segmen pasar kelas atas, yang mengandalkan keunggulan kinerja produk serta kemampuannya untuk menunjukkan gaya hidup pemakainya, umumnya memiliki pelanggan-pelanggan yang loyal. Meski 


\section{Claudia Lorenzia Core, dan Ni Wayan Sri Suprapti. Niat Konsumen Membeli...}

tetap berupaya untuk meraih pelanggan baru dari segmen pasar lainnya, penjualan merek-merek produk seperti ini banyak diperoleh dari kontribusi pembelian oleh pelanggan-pelanggannya yang setia melalui pembelian kembali (repurchase).

Dalam studi pemasaran, niat beli ulang (repurchase intention) merupakan isu yang menarik untuk diteliti. Hal ini dikarenakan niat beli ulang adalah penyebab terjadinya perilaku sehingga dapat menjadikan masukan bagi pemilik maupun pemasar untuk menyusun strategi pemasaran yang tepat agar meningkatkan niat konsumen untuk melakukan pembelian ulang pada produk yang ditawarkan sehingga pada akhirnya akan meningkatkan profitabilitas dan keberlanjutan perusahaan. Penelitian ini bertujuan untuk menjelaskan : (1) pengaruh inersia konsumen terhadap niat beli ulang produk smartphone merek iPhone ; (2) pengaruh nilai mewah terhadap kepuasan pelanggan produk smartphone merek iPhone ; (3) pengaruh atribut produk terhadap kepuasan pelanggan produk smartphone merek iPhone ; (4) pengaruh kepuasan pelanggan terhadap niat beli ulang produk smartphone merek iPhone ; (5) pengaruh atribut produk terhadap niat beli ulang produk smartphone merek iPhone, dan (6) peran aspek sosial dalam memoderasi hubungan antara inersia konsumen dan niat pembelian ulang produk smartphone merek iPhone.

Solomon (2007) menegaskan bahwa faktor inersia mempengaruhi keputusan pembelian ulang. Inersia membuat konsumen menghindar untuk berurusan dengan produk yang tidak familiar sehingga konsumen dengan inersia yang tinggi akan setia dengan produk yang sekarang ia gunakan dan akan mengulang pembelian dengan sendirinya (Gulati, 1995). Konsumen yang didorong inersia juga kurang termotivasi 


\section{E-Jurnal Ekonomi dan Bisnis Universitas Udayana 7.6 (2018): 1565-1588}

untuk mempertimbangkan alternatif produk (Colgate dan Lang, 2011). Ini menjadi dasar pengembangan hipotesis yang diajukan, yaitu:

H1: Inersia konsumen berpengaruh positif dan signifikan terhadap niat pembelian ulang produk smartphon

Pemikiran utama pasar produk mewah adalah pentingnya konsumsi yang memuaskan satu orang (Tsai, 2005).Konsumen yang mencari kualitas tinggi dan produk dengan reputasi tinggi akan memiliki patokan kepuasan yang tinggi (Pitt et al., 2009). Nilai yang dilambangkan suatu produk memainkan peran penting dalam mempengaruhi kepuasan pelanggan (Bian dan Forsythe, 2012; Tsai, 2005). Ini menjadi dasar pengembangan hipotesis yang diajukan, yaitu:

H2: Nilai mewah berpengaruh positifdan signifikan terhadap kepuasan pelanggan produk smartphone.

Anderson dan Mittal (2000) mengusulkan bahwa atribut produk adalah pusat dari peningkatan kualitas dan kepuasan pelanggan. Hal ini penting untuk menyajikan atribut produk kualitas tinggi, karena akan sangat meningkatkan pengalaman konsumen dan karena itu, memimpin untuk mengulang keputusan pembelian.Ini menjadi dasar pengembangan hipotesis yang diajukan, yaitu:

H3: Atribut produk berpengaruh positif dan signifikan terhadap kepuasan pelanggan produk smartphone.

Kepuasan mengacu pada kepuasan menyeluruh yang dirasakan pelanggan karena kemampuan perusahaan memenuhi keinginan, harapan dan kebuthan pelanggannya. Sementara niat beli ulang mengacu pada pertimbangan seseorang 


\section{Claudia Lorenzia Core, dan Ni Wayan Sri Suprapti. Niat Konsumen Membeli...}

untuk membeli kembali sebuah produk dari perusahaan yang sama (Ibzan et al. 2016).Henkel et al. (2006) menemukan bahwa pelanggan yang puas dengan produk yang diberikan perusahaan akan berusaha meningkatkan penggunaan dan niat pembelian mereka dimasa depan.Ini menjadi dasar pengembangan hipotesis yang diajukan, yaitu:

H4: Kepuasan pelanggan berpengaruh positif dan signifikan terhadap niat pembelian ulang produk smartphone.

Model informasi yang dilakukan oleh Engel et al. (1986) telah menyoroti bahwa konsumen akan mengumpulkan informasi berharga dan melakukan evaluasi sebelum membuat keputusan pembelian terakhir mereka. Sepanjang proses ini, atribut produk menjadi elemen penting untuk membentuk dasar dari evaluasi (Zhang et al., 2002). Karakteristik yang berbeda dari produk akan berbeda pentingnya dalam pikiran konsumen, sehingga mempengaruhi kriteria seleksi dalam keputusan pembelian. Ini menjadi dasar pengembangan hipotesis yang diajukan, yaitu:

H5: Atribut produk berpengaruh positifdan signifikan terhadap niat pembelian ulang produk smartphone

Tanpa adanya paksaan atau pengaruh lain, konsumen akan tetap pada pilihan produk yang sekarang dan dengan adanya barang pengganti yang lebih menarik konsumen akan tetap melekat pada produk yang sedang ia gunakan jika mereka memiliki inersia yang tinggi ( $\mathrm{Li} \mathrm{Hu}$, 2013).Dalam konteks perilaku konsumen, pengaruh sosial dapat mempengaruhi perilaku pembelian seseorang. Nelson dan McLeod (2005) menyatakan bahwa konsumen akan dipengaruhi media, orang tua dan teman sebaya nya dalam membeli smartphone. Mereka akan meminta saran dan 


\section{E-Jurnal Ekonomi dan Bisnis Universitas Udayana 7.6 (2018): 1565-1588}

nasihat dari pengalaman mereka yang sudah menggunakan smartphone tersebut (Kotler dan Armstrong, 2007). Ini menjadi dasar pengembangan hipotesis yang diajukan, yaitu:

H6: Aspek sosial berpengaruh positifdan signifikan terhadap hubungan antara inersia konsumen dan niat pembelian ulang produk smartphone

Berdasarkan hasil penelusuran teori, konsep dan hasil-hasil studi empiris sebelumnya, maka model penelitian dapat disajikan seperti Gambar 1.

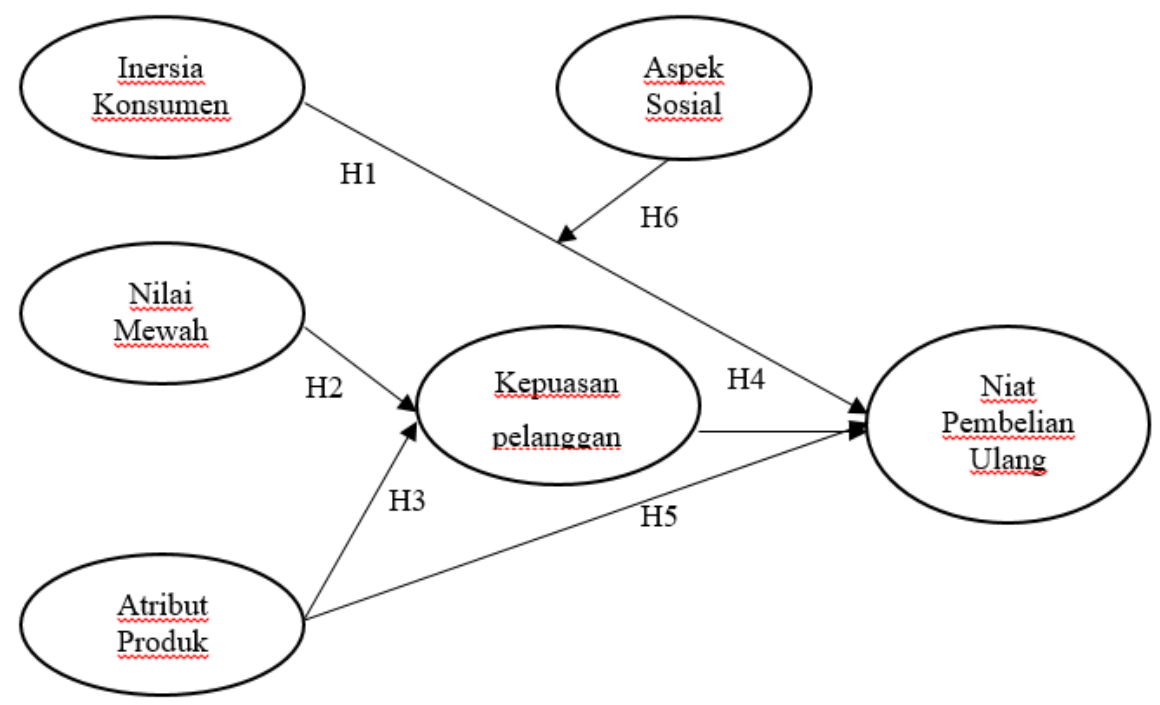

Gambar 1. Model Penelitian

\section{METODE PENELITIAN}

Penelitian yang dilakukan di Kota Denpasar ini merupakan penelitian asosiatif karena meneliti pengaruh faktor-faktor kunci yang menentukan niat pembelian ulang 


\section{Claudia Lorenzia Core, dan Ni Wayan Sri Suprapti. Niat Konsumen Membeli...}

produk smartphone merek iPhone. Sumber data dalam penelitian ini terdiri atas sumber primer dan sekunder. Sumber primer adalah didapatkan dari jawaban pihak responden terhadap kuesioner yaitu berupa identitas responden dan persepsi responden tentang inersia konsumen, nilai mewah, atribut produk, kepuasan pelanggan, aspek sosial dan niat beli ulang. Sedangkan sumber sekunder adalah website Databoks, Katadata Indonesia. Setiap variabel penelitian diukur dengan indikator. Masing-masing variabel penelitian memiliki empat indikator yang diadopsi dari studi Lee dan Neale (2012) serta Goh et al. (2016).

Sampel dalam penelitian adalah bagian dari populasi pengguna smartphone merek iPhone yang diambil dengan menggunakan teknik purposive sampling. Pertimbangan yang digunakan yaitu 154 konsumen produk smartphone yang sedang menggunakan produk smartphone merek iPhone, berdomisili di kota Denpasar dan sudah lulus SMA. Data dalam penelitian ini dikumpulkan melalui penyebaran kuisioner kepada responden penelitian berkaitan dengan tanggapannya terhadap variabel inersia konsumen, nilai mewah, atribut produk kepuasan pelanggan, pengaruh sosial dan niat pembelian ulang produk smartphone merek iPhone. Kuesioner yang disebarkan oleh peneliti melalui tatap muka langsung, melalui $e$-mail dan juga dibantu beberapa orang teman sebagai perantara ini terbagi atas dua bagian, yaitu pertama identitas lengkap dengan info demografis responden. Lalu bagian kedua yaitu penilaian responden terhadap masing-masing variabel penelitiian yang diukur lewat indikatornya masing-masing. Skala pengukuran variabel menggunakan Skala Likert lima poin yang dipakai untuk memberi bobot pada masing-masing 


\section{E-Jurnal Ekonomi dan Bisnis Universitas Udayana 7.6 (2018): 1565-1588}

indikator dalam penelitian ini adalah $1=$ sangat tidak setuju, $2=$ tidak setuju, $3=$ netral, $4=$ setuju, $5=$ sangat setuju.

\section{HASIL DAN PEMBAHASAN}

\section{Profil Responden}

Hasil penelitian terhadap responden penelitian menunjukkan bahwa pengguna smartphone merek iPhone didominasi pada rentang usia 21-25 tahun dengan jumlah 86 orang.Dari jumlah responden sebanyak 154 orang juga ditemukan bahwa 91 orang responden adalah perempuan. Pada kategori pendidikan terakhir ditemukan bahwa sebanyak 114 orang responden merupakan tamatan Strata-1. Pekerjaan yang dimiliki setiap responden juga bervariasi dimana mayoritas responden berprofesi sebagai karyawan swasta. Selanjutnya, karena karakteristik responden yang utama adalah mereka yang sedang aktif menggunakan smartphone merek iPhone, maka melalui penyebaran kuesioner dapat diketahui sebanyak 126 orang responden sudah menggunakan smartphone merek iPhone selama lebih dari 1 tahun. Dan sebanyak 100 orang menyatakan bahwa mereka belum pernah mengganti smartphone dalam 1 tahun terakhir.

\section{Hasil Pengujian Instrumen Penelitian}

Hasil uji validitas untuk mengukur valid tidaknya kuesioner penelitian menunjukkan bahwa semua indikator memiliki koefisien korelasi diatas 0,5 sehingga butir pernyataan dalam kuesioner dikatakan valid. Uji reliabilitas yang dilakukan untuk mengetahui derajat stabilitas, konsistensi, daya prediksi dan akurasi sebuah instrument penelitianmenunjukkan nilai koefisien alpha seluruh variabel adalah > 


\section{Claudia Lorenzia Core, dan Ni Wayan Sri Suprapti. Niat Konsumen Membeli...}

0,60 dimana nilai tersebut sudah memenuhi kriteria nilai yang diterima, sehingga keenam variabel yang diteliti reliabel atau handal.

\section{Tabel 1 Indikator Variabel Penelitian dan Hasil Pengujian Validitas dan Reliabilitas}

\begin{tabular}{|c|c|c|c|c|c|}
\hline \multirow[t]{2}{*}{ No } & \multirow[t]{2}{*}{ Variabel } & \multirow[t]{2}{*}{ Indikator } & Validitas & Reliabilitas & \multirow[t]{2}{*}{ Sumber } \\
\hline & & & $\begin{array}{l}\text { Koefisien } \\
\text { Korelasi }\end{array}$ & $\begin{array}{l}\text { Koefisien } \\
\text { Alpha }\end{array}$ & \\
\hline \multirow[t]{4}{*}{1} & \multirow{4}{*}{$\begin{array}{l}\text { Inersia } \\
\text { Konsumen } \\
\left(\mathrm{X}_{1}\right)\end{array}$} & a. Akrab dengan fitur dan fungsi & 0,870 & \multirow[t]{4}{*}{0,913} & \multirow{4}{*}{$\begin{array}{l}\text { Lee dan } \\
\text { Neale (2012) } \\
\text { Goh et al. } \\
(2016)\end{array}$} \\
\hline & & b. Tidak berpikir untuk beralih & 0,887 & & \\
\hline & & c. Tidak melihat penawaran lain & 0,918 & & \\
\hline & & d. Malas/lembam untuk beralih & 0,886 & & \\
\hline \multirow[t]{4}{*}{2.} & \multirow{4}{*}{$\begin{array}{l}\text { Nilai } \\
\text { Mewah } \\
\left(\mathrm{X}_{2}\right)\end{array}$} & a. Status/Reputasi Produk & 0,867 & \multirow[t]{4}{*}{0,895} & \multirow{4}{*}{$\begin{array}{l}\text { Goh et al. } \\
(2016)\end{array}$} \\
\hline & & b. Keunikan produk & 0,868 & & \\
\hline & & c. Keeksklusifan produk & 0,843 & & \\
\hline & & d. Produk berkarakter & 0,916 & & \\
\hline \multirow[t]{4}{*}{3.} & Atribut & a. Produk bervariasi & 0,891 & \multirow[t]{4}{*}{0,912} & \multirow{4}{*}{$\begin{array}{l}\text { Goh et al. } \\
(2016)\end{array}$} \\
\hline & \multirow[t]{3}{*}{$\begin{array}{l}\text { Produk } \\
\left(\mathrm{X}_{3}\right)\end{array}$} & $\begin{array}{ll}\text { b. Pengalaman } & \text { layanan } \\
\text { pelanggan }\end{array}$ & 0,836 & & \\
\hline & & c. Produk selalu berinovasi & 0,909 & & \\
\hline & & $\begin{array}{l}\text { d. Produk berkualitas, memiliki } \\
\text { fitur canggih dan desain } \\
\text { menarik }\end{array}$ & 0,926 & & \\
\hline \multirow[t]{4}{*}{4.} & \multirow{4}{*}{$\begin{array}{l}\text { Kepuasan } \\
\text { Pelanggan } \\
\left(\mathrm{Y}_{1}\right)\end{array}$} & a. Puas terhadap kinerja produk & 0,714 & \multirow[t]{4}{*}{0,677} & \multirow{4}{*}{$\begin{array}{l}\text { Goh et al. } \\
(2016)\end{array}$} \\
\hline & & b. Puas terhadap desain produk & 0,405 & & \\
\hline & & c. Puas terhadap nilai produk & 0,731 & & \\
\hline & & $\begin{array}{l}\text { d. Puas terhadap eksklusivitas } \\
\text { produk }\end{array}$ & 0,848 & & \\
\hline \multirow[t]{4}{*}{5.} & \multirow{4}{*}{$\begin{array}{l}\text { Aspek } \\
\text { Sosial } \\
\text { (Moderator) }\end{array}$} & $\begin{array}{l}\text { a. Bagian dari komunitas } \\
\text { tertentu }\end{array}$ & 0,880 & \multirow[t]{4}{*}{0,881} & \multirow[t]{4}{*}{$\begin{array}{l}\text { Goh et al. } \\
(2016)\end{array}$} \\
\hline & & $\begin{array}{l}\text { b. Rekomendasi dari orang- } \\
\text { orang terdekat }\end{array}$ & 0,815 & & \\
\hline & & c. Referensi dari role model & 0,850 & & \\
\hline & & $\begin{array}{l}\text { d. Menunjang peran dan status } \\
\text { sosial }\end{array}$ & 0,888 & & \\
\hline \multirow[t]{4}{*}{6.} & \multirow[t]{4}{*}{$\begin{array}{l}\text { Niat Beli } \\
\text { Ulang }\left(\mathrm{Y}_{2}\right)\end{array}$} & $\begin{array}{l}\text { a. Produk menjadi pertimbangan } \\
\text { utama }\end{array}$ & 0,908 & \multirow[t]{4}{*}{0,925} & \multirow[t]{4}{*}{$\begin{array}{l}\text { Goh et al. } \\
(2016)\end{array}$} \\
\hline & & $\begin{array}{l}\text { b. Pasti akan memilih produk } \\
\text { yang sama }\end{array}$ & 0,882 & & \\
\hline & & $\begin{array}{l}\text { c. Tidak akan memilih produk } \\
\text { lain }\end{array}$ & 0,921 & & \\
\hline & & $\begin{array}{l}\text { d. Akan memilih produk dalam } \\
\text { pembelian berikutnya }\end{array}$ & 0,907 & & \\
\hline
\end{tabular}

Sumber: Data diolah 


\section{E-Jurnal Ekonomi dan Bisnis Universitas Udayana 7.6 (2018): 1565-1588}

\section{Hasil Pengujian Model Struktural}

Hasil pengujian pada Tabel 2 menunjukkan bahwa semua konstruk yang yang membentuk model penelitian telah memenuhi kriteria goodness of fit index yang telah ditetapkan. Untuk indeks kesesuaian probability, RMSEA, CMIN/DF, TLI dan CFI nilai hasil modelnya sudah sesuai dengan kriteria yang telah ditetapkan sedangkan untuk GFI dan AGFI nilai hasil modelnya berada dibawah cut-off value. Namun nilai tersebut masih dalam batas toleransi atau marginal yang artinya model sesuai dengan data sampel.

Tabel 2

Hasil Pengujian Model Struktural

\begin{tabular}{lccc}
\hline $\begin{array}{c}\text { Goodness offit } \\
\text { index }\end{array}$ & $\begin{array}{c}\text { Cut }- \text { off } \\
\text { value }\end{array}$ & Hasil Model & Keterangan \\
\hline Chi-square & $\begin{array}{c}\text { Diharapkan } \\
\text { kecil }\end{array}$ & 297,364 & Baik \\
\hline Probability & $\geq 0,05$ & 0,098 & Baik \\
\hline RMSEA & $\leq 0,08$ & 0,027 & Baik \\
\hline GFI & $\geq 0,90$ & 0,873 & Marginal \\
\hline AGFI & $\geq 0,90$ & 0,846 & Marginal \\
\hline CMIN/DF & $\leq 2,00$ & 1,114 & Baik \\
\hline TLI & $\geq 0,95$ & 0,986 & Baik \\
\hline CFI & $\geq 0,95$ & 0,987 & Baik \\
\hline
\end{tabular}

Sumber: Data diolah

\section{Pengujian Hipotesis}

Tabel 3 Hasil Pengujian Hipotesis

\begin{tabular}{lcccc}
\hline Hubungan Variabel & Estimate & S.E. & C.R. & P \\
\hline Inersia $\rightarrow$ NBU & .038 & .080 & .424 & .671 \\
\hline Nilai Mewah $\rightarrow$ Kepuasan pelanggan & .318 & .075 & 3.634 & $* * *$ \\
\hline Atribut Produk $\rightarrow$ Kepuasan Pelanggan & .502 & .104 & 4.895 & $* * *$ \\
\hline Kepuasan Pelanggan $\rightarrow$ NBU & .460 & .105 & 4.865 & $* * *$ \\
\hline Atribut Produk $\rightarrow$ NBU & .333 & .106 & 3.565 & $* * *$ \\
\hline X1X4 (variabel moderasi) $\rightarrow$ NBU & .358 & .001 & 3.112 & .002 \\
\hline
\end{tabular}

Sumber: Data diolah 


\section{Claudia Lorenzia Core, dan Ni Wayan Sri Suprapti. Niat Konsumen Membeli...}

\section{Pembahasan Hasil Pengujian Hipotesis}

\section{Pengaruh Inersia Konsumen Terhadap Niat Beli Ulang}

Inersia konsumen ditemukan tidak berpengaruh terhadap niat beli ulang produk smartphone merek iPhone. Hasil uji terhadap parameter estimasi antara inersia konsumen dengan niat beli ulang menunjukkan adanya pengaruh sebesar $0,038(\mathrm{p}>0,05)$ dan karena nilai $\mathrm{p}$ lebih besar dari 0,05, ini berarti hipotesis pertama tidak memperoleh dukungan. Ini berarti pengguna smartphone merek iPhone di kota Denpasar tidak memiliki kelembaman atau kemalasan untuk bertahan dengan smartphone tersebut. Dengan kata lain pengguna smartphone merek iPhone masih berpikir untuk beralih dan mencari penawaran menarik dari smartphone merek lainnya. Keadaan tersebut menggambarkan pengguna yang memiliki inersia yang rendah, dimana pengguna produk dengan inersia yang rendah cenderung mencari produk selingan atau lainnya ketika mereka merasa bosan dengan produk yang sudah rutin digunakan (Va 'zquez-Carrasco dan Foxall, 2006).

Hal ini bertentangan dengan penelitian sebelumnya oleh Goh et al. (2016) bahwa inersia konsumen berpengaruh terhadap niat pembelian ulang. Disamping itu hasil penelitian ini juga bertentangan dengan penyataan Liu et al. (2007) yaitu bahwa inersia bisa mendorong untuk mengulang pembelian. Begitu juga dengan pendapat Solomon (2007) yang menegaskan bahwa konsumen yang didorong inersia membuat keputusan pembelian tanpa banyak pertimbangan. Dalam penelitian peneliti menemukan bahwa ada beberapa responden yang menyatakan bahwa mereka tidak berniat membeli ulang smartphone merek iPhone karena faktor harga yang tinggi. Ini berarti pengguna smartphone merek iPhone masih mempertimbangkan unsur harga 


\section{E-Jurnal Ekonomi dan Bisnis Universitas Udayana 7.6 (2018): 1565-1588}

sebelum membeli ulang. Sehingga dengan demikian hasil penelitian menunjukkan hasil yang berbeda dengan konsep yang diajukan karena inersia tidak berhasil mempengaruhi niat pengguna smartphone merek iPhone di kota Denpasar.

\section{Pengaruh Nilai Mewah Terhadap Kepuasan Pelanggan}

Nilai mewah ditemukan berpengaruh terhadap kepuasan pelanggan smartphone merek iPhone.Hasil uji terhadap parameter estimasi antara nilai mewah dengan kepuasan pelanggan menunjukkan adanya pengaruh sebesar 0,318 $(\mathrm{p}<0,05)$ dan karena nilai p lebih kecil dari 0,05 ini berarti hipotesis kedua memperoleh dukungan. Ini berarti bahwa smartphone merek iPhone dengan eksklusivitasnya dan bahwa ia mampu memberi karakter bagi penggunanya berhasil memberikan kepuasan. Pengguna smartphone merek iPhone juga setuju bahwa menggunakan smartphone tersebut dapat memberi status dan reputasi bagi dirinya. Hal ini sesuai dengan yang dikatakan Bian dan Forsythe (2012) bahwa konsumen dalam perkumpulan tertentu memiliki norma, nilai dan pemahaman yang sama, sehingga mereka membeli produk mewah dengan maksud memamaerkan statusnya pada anggota lain dalam perkumpulan tersebut. Selaras dengan hasil penelitian sebelumnya bahwa nilai yang dilambangkan suatu produk memainkan peran penting dalam mempengaruhi kepuasan pelanggan (Bian dan Forsythe, 2012; Tsai, 2005). Pitt et al. (2009) juga menjabarkan bahwa persepsi konsumen akan nilai mewah pada suatu

produk menandakan pengalaman emosional dan nilai simbolik terhadap produk tersebut. Dengan kata lain konsumen yang mencari kualitas tinggi dan produk dengan reputasi tinggi akan memiliki patokan kepuasan yang tinggi pula.Sehingga dengan 


\section{Claudia Lorenzia Core, dan Ni Wayan Sri Suprapti. Niat Konsumen Membeli...}

demikian hasil penelitian menunjukkan bahwa nilai mewah yang dirasakan selama menggunakan smartphone merek iPhone berhasil memberi kepuasan terhadap pengguna smartphone tersebut.

\section{Pengaruh Atribut Produk Terhadap Kepuasan Pelanggan}

Atribut produk ditemukan berpengaruh terhadap kepuasan pelanggan smartphone merek iPhone. Hasil uji terhadap parameter estimasi antara atribut produk dengan kepuasan pelanggan menunjukkan adanya pengaruh sebesar 0,502 $(\mathrm{p}<0,05)$ dan karena nilai $\mathrm{p}$ lebih kecil dari 0,05 ini berarti hipotesis ketiga memperoleh dukungan. Ini berarti pengguna smartphone merek iPhone di kota Denpasar setuju bahwa menggunakan iPhone memberi jaminan kualitas produk yang sesuai dengan produk lainnya dalam grup Apple dan merasa bahwa iPhone adalah smartphone yang berkualitas, memiliki fitur canggih serta desain yang menarik. Atribut produk dirancang untuk mencapai tingkat kepuasan dari kebutuhan dan keinginan konsumen dengan memiliki, memakai dan memanfaatkan produk tersebut (Kotler, Philip, Armstrong, dan Gary, 2007). Hasil analisis ini didukung oleh penelitian Gerpott et al. (2001) dimana dasar dari kepuasan adalah pengalaman konsumen terhadap produk dimana perusahaan mampu memenuhi harapan konsumen tersebut. Selain itu Chow et al. (2012) menambahkan bahwa konsumen masa kini menyadari atribut yang berbeda akan memberi tingkat kepuasan yang juga berbeda terhadap smartphone.Wickliffe dan Psyarchik (2001) juga menambahkan bahwa konsumen memilih produk berdasarkan atributnya yang akan memberikan manfaat yang lebih spesifik untuk mendukung nilai-nilai pribadi. Dengan demikian maka hasil penelitian menunjukkan bahwa selama menggunakan dan memanfaatkan atribut dan 


\section{E-Jurnal Ekonomi dan Bisnis Universitas Udayana 7.6 (2018): 1565-1588}

fitur smartphone merek iPhone, pengguna merasa puas terhadap jaminan kualitas dan desain produk smartphone tersebut.

\section{Pengaruh Kepuasan Pelanggan Terhadap Niat Beli Ulang}

Kepuasan pelanggan ditemukan berpengaruh terhadap niat beli ulang produk smartphone merek iPhone.Hasil uji terhadap parameter estimasi antara kepuasan pelanggan dengan niat pembelian ulang menunjukkan adanya pengaruh sebesar 0,460 $(\mathrm{p}<0,05)$ dan karena nilai $\mathrm{p}$ lebih kecil dari 0,05 ini berarti hipotesis keempat memperoleh dukungan. Ini berarti niat pengguna smartphone di kota Denpasar untuk membeli ulang disebabkan kepuasan yang dirasakan ketika menggunakan smartphone tersebut. Kepuasan yang dimaksud datang dari rasa puas terhadap : kinerja smartphone yang dirasakan ketika mengoperasikan smartphone merek iPhone, desain model yang ditampilkan, nilai yang diberikan dan khususnya eksklusivitas smartphone merek iPhone sehingga kepuasan ini mendorong niat untuk membeli ulang produk yang sama dipembelian berikutnya. Dalam penelitian sebelumnya Lee et al. (2009) menyatakan bahwa pelanggan yang puas memiliki kemungkinan lebih tinggi untuk kembali ke merek yang sama dengan yang ia beli sebelumnya. Hasil penelitian ini juga didukung oleh Kuo et al. (2013) bahwa konsumen yang memiliki kepuasan yang tinggi akan berulang kali kembali ke vendor yang sama untuk mendapatkan hasil yang optimal. Dengan demikian maka hasil penelitian menunjukkan bahwa niat beli ulang produk smartphone merek iPhone disebabkan oleh kepuasan yang dirasakan pengguna smartphone tersebut.

\section{Pengaruh Atribut Produk Terhadap Niat Beli Ulang}




\section{Claudia Lorenzia Core, dan Ni Wayan Sri Suprapti. Niat Konsumen Membeli...}

Atribut produk ditemukan berpengaruh terhadap niat beli ulang produk smartphone merek iPhone. Hasil uji terhadap parameter estimasi antara atribut produk dengan niat beli ulang menunjukkan adanya pengaruh sebesar $0,333(\mathrm{p}<0,05)$ dan karena nilai $\mathrm{p}$ lebih kecil dari 0,05 ini berarti hipotesis kelima memperoleh dukungan.

Ini berarti berarti niat pengguna smartphone di kota Denpasar untuk membeli ulang disebabkan atribut produk yang ada pada smartphone merek iPhone. Atribut produk terbagi atas dua yaitu hardware dan software.Hardware adalah wujud fisik (ukuran, model, warna dan berat) dari smartphone tersebut sedangkan software adalah sistem yang mengoperasikan smartphone dan memori penyimpanan (Lay-Yee et al. 2013). Atribut-atribut ini dapat dirasakan dengan memiliki, menggunakan dan memanfaatkan produk sehingga melalui ketiga hal tersebut konsumen memiliki dasar pengambilan keputusan pembelian (Tjiptono, 2001). Hal yang sama juga dikemukakan oleh Kotler dan Armstrong (2007) bahwa karakteristik yang berbeda dari produk akan berbeda pentingnya didalam pikiran konsumen sehingga akan mempengaruhi kriteria seleksi dalam keputusan pembelian. Dengan demikian maka hasil penelitian menunjukkan bahwa niat beli ulang produk smartphone merek iPhone disebabkan oleh pengalaman terhadap atribut produk yang dirasakan pengguna smartphone tersebut.

\section{Peran Aspek Sosial Dalam Memoderasi Hubungan Antara Inersia Konsumen dan Niat Beli Ulang}

Aspek sosial ditemukan memoderasi hubungan antara inersia konsumen dengan niat beli ulang produk smartphone merek iPhone.Hasil uji terhadap parameter 


\section{E-Jurnal Ekonomi dan Bisnis Universitas Udayana 7.6 (2018): 1565-1588}

estimasi antara variabel interaksi X1X4 dengan niat beli ulang menunjukkan adanya pengaruh sebesar 0,358 $(\mathrm{p}<0,05)$ dan karena nilai $\mathrm{p}$ lebih kecil dari 0,05 maka hipotesis ketujuh memperoleh dukungan. Hal ini menunjukkan bahwa ditengahtengah hubungan antara inersia konsumen dengan niat beli ulang yang dipembahasan sebelumnya tidak didukung, adanya aspek sosial ternyata memperkuat hubungan inersia konsumen dengan niat beli ulang. Dengan kata lain, yang awalnya inersia tidak mendorong munculnya niat beli ulang, namun dengan pengaruh dari aspek sosial, niat beli ulang smartphone merek iPhone itu pun muncul. Ini artinya pengguna smartphone merek iPhone yang tidak didorong inersia dan masih tertarik pada smartphone merek lain, jika mereka berhasil dipengaruhi oleh lingkungan sekitarnya (keluarga, teman sebaya dan kelompok) maka niat untuk membeli ulang smartphone merek iPhone dengan tipe yang berbeda akan muncul. Hasil penelitian ini selaras dengan penelitian sebelumnya oleh Goh et al. 2016 yang juga memberi hasil dimana aspek sosial memoderasi (memperkuat) hubungan inersia konsumen dan niat pembelian ulang.

\section{Implikasi Penelitian}

Hasil penelitian ini memiliki implikasi teoritis dan praktis. Secara teoritis hasil penelitian ini memberi informasi bahwa variabel-variabel yang menyebabkan kepuasan sehingga menimbulkan niat beli ulang produk smartphone merek iPhone adalah nilai mewah dan atribut produk. Hasil analisis data pada pembahasan sebelumnya juga menunjukkan bahwa atribut produk memiliki hubungan dengan nilai paling besar $(0,502)$ terhadap kepuasan pelanggan. Ini artinya pengguna 


\section{Claudia Lorenzia Core, dan Ni Wayan Sri Suprapti. Niat Konsumen Membeli...}

smartphone merek iPhone di kota Denpasar merasa lebih puas terhadap atribut dan fitur yang didapat daripada nilai mewah yang dirasakan selama menggunakan smartphone tersebut. Sehingga kepuasan tersebut menjadi dasar pengambilan keputusan untuk membeli ulang smartphone dari merek yang sama.

Selain itu hasil penelitian juga menunjukkan bahwa inersia konsumen tidak berpengaruh terhadap niat pembelian ulang, namun aspek sosial terbukti memoderasi atau memperkuat hubungan inersia konsumen dengan niat pembelian ulang. Maka hasil penelitian ini dapat menjadi acuan untuk memperdalam penelitian tentang inersia konsumen terhadap niat pembelian ulang untuk melihat hasil yang berbeda.

Hasil temuan lain dalam penelitian ini adalah nilai mewah berpengaruh terhadap kepuasan pelanggan serta kepuasan pelanggan juga terbukti memediasi hubungan antara atribut produk dengan niat pembelian ulang. Dengan temuan ini maka hasil penelitian dapat memperkaya ilmu manajemen pemasaran khususnya di bidang perilaku konsumen untuk mendukung studi-studi empiris lainnya yang berkaitan dengan faktor-faktor yang mendorong niat pembelian ulang.

Secara praktis hasil temuan pertama dalam penelitian ini menunjukkan bahwa inersia konsumen tidak berpengaruh terhadap niat pembelian ulang, maka yang perlu diperhatikan adalah bagaimana membuat konsumen merasa enggan untuk beralih ke produk smartphone merek lain walaupun ada banyak penawaran smartphone merek lain yang lebih menarik. Temuan kedua dalam penelitian ini yaitu nilai mewah berpengaruh terhadap kepuasan pelanggan. Hal ini dapat menjadi masukan bagi perusahaan Apple untuk mempertahankan nilai-nilai simbolik dan fungsional iPhone yang menjadi daya tarik produk ini. Dengan menciptakan nilai yang tidak didapatkan 


\section{E-Jurnal Ekonomi dan Bisnis Universitas Udayana 7.6 (2018): 1565-1588}

dari produk smartphone merek lain maka iPhone akan unggul dan memberi kepuasan pada konsumen setianya. Dan tentu saja akan meningkatkan profitabilitas karena konsumen yang puas cenderung akan loyal. Hasil penelitian ini juga berkaitan dengan hasil temuan dimana kepuasan pelanggan memediasi hubungan antara atribut produk dengan niat pembelian ulang. Artinya penting untuk perusahaan Apple untuk memastikan konsumennya puas dengan atribut produk yang ditawarkan.

Temuan selanjutnya adalah bahwa aspek sosial terbukti memoderasi atau memperkuat hubungan inersia konsumen dengan niat pembelian ulang. Aspek sosial berkaitan dengan interaksi setiap mahluk sosial. Sehingga yang perlu manajemen Apple perhatikan disini adalah untuk meningkatkan gengsi komunitas pengguna smartphone merek iPhone sehingga melalui komunitas ajakan untuk tetap menggunakan smartphone tersebut dan tetap mencari penawaran menarik dari Apple saja dapat semakin diperkuat sehingga dapat meningkatkan niat beli ulang.

\section{SIMPULAN DAN SARAN}

Penelitian ini menunjukkan hasil bahwa : (1) Inersia konsumen tidak berpengaruh terhadap niat pembelian ulang, artinya perilaku membeli ulang konsumen smartphone merek iPhone di kota Denpasar tidak dipengaruhi oleh keakraban dengan fungsi produk dan rasa malas untuk beralih ke smartphone merek lain. Pengguna smartphone merek iPhone juga masih melihat penawaran menarik dari smartphone merek lain. (2) Nilai mewah berpengaruh positif terhadap kepuasan pelanggan, artinya nilai-nilai yang diberikan oleh smartphone merek iPhone seperti reputasi produk, keunikan produk, eksklusivitas produk dan bahwa produk mampu 


\section{Claudia Lorenzia Core, dan Ni Wayan Sri Suprapti. Niat Konsumen Membeli...}

memberi karakter bagi penggunanya mampu memberi kepuasan bagi konsumen di Kota Denpasar. (3) Atribut produk berpengaruh positif terhadap kepuasan pelanggan, artinya inovasi yang selalu dilakukan baik oleh smartphone merek iPhone maupun produk terkait yang ada dalam kategori produk merek Apple mampu memberi kepuasan bagi penggunanya yang ada di Kota Denpasar. (4) Kepuasan pelanggan berpengaruh positifterhadap niat pembelian ulang, artinya konsumen smartphone merek iPhone kota Denpasar merasa puas terhadap kinerja, desain model, nilai yang diberikan serta keeksklusifan smartphone merek iPhone sehingga mendorong niat membeli ulang produk yang sama di masa depan.(5) Atribut produk berpengaruh positifterhadap niat pembelian ulang, artinya pandangan konsumen smartphone merek iPhone kota Denpasar mengganggap atribut produk sebagai alasan membeli ulang produk smartphone merek iPhone. (6) Aspek sosial memoderasi atau memperkuat hubungan inersia konsumen dan niat pembelian ulang artinya niat konsumen smartphone merek iPhone di kota Denpasar membeli ulang produk smartphone merek iPhone diperkuat oleh interaksinya dengan orang-orang terdekat mereka dan lingkungan sosialnya.

Beberapa hal yang dapat disarankan bagi pihak-pihak terkait sehubungan hasil studi ini adalah sebagai berikut :

1. Niat konsumen di Kota Denpasar untuk membeli ulang smartphone merek iPhone ditentukan oleh atribut yang didapat pada smartphone tersebut dan juga kepuasan yang dirasakan atas penggunaan dan pengalaman memanfaatkan atribut smartphone tersebut. Karena itu, manajemen produk 


\section{E-Jurnal Ekonomi dan Bisnis Universitas Udayana 7.6 (2018): 1565-1588}

Apple agar mampu berinovasi pada fitur dan desain dan meningkatkan kualitasproduk smartphone merek iPhone agar konsumen tidak mencari penawaran menarik dari smartphone merek lain serta memberi kepuasan. Selain itu nilai mewah yang terdapat pada smartphone merek iPhone juga menentukan kepuasan konsumen di Kota Denpasar terhadapsmartphone tersebut. Sehingga perlu bagi manajemen produk Apple meningkatkan eksklusivitas dan keunikan dari smartphone merek iPhone.

2. Penelitian ini hanya meneliti produk smartphone yang masuk kategori mewah, sehingga diharapkan peneliti berikutnya untuk meneliti jenis produk lainnya yang masuk kategori produk mewah, dimana produk tersebut dapat diamati dan menunjukkan gengsi seseorang atau sekumpulan masyarakat tertentu.

\section{REFERENSI}

Ahuvia, A.C. (2005), "Beyond the extended self: loved objects and consumers' identity narratives", Journal of Consumer Research, Vol. 32 No. 1, pp. 171184.

Akhter, S.H. (2010), Services Attributes Satisfaction and Actual Repurchase Behavior: The Mediating Influence of Overall Satisfaction and Purchase Intention. Journal of Customer Satisfaction, Dissatisfaction and Complaining Behavior, 23:52-64.

Anderson, R.E., Srinivasan, S.S. (2003), E-satisfaction and e-loyalty: A contingency framework. Psychology and Marketing, Vol. 20, No. 2, pp. 123-138.

Anderson, E. W., dan Mittal. (2000), "Strengthening the Satisfaction-Profit Chain." Journal of Service Research, November, Vol. 3, pp. 170-120 


\section{Claudia Lorenzia Core, dan Ni Wayan Sri Suprapti. Niat Konsumen Membeli...}

Ang, S.H., Cheng, P.S., Lim, E.A., Tambyah, S. (2001), Spot the difference: Consumer responses towards counterfeits. Journal of Consumer Marketing, Vol. 18, No. 3, pp. 219-235.

Anoraga, Pandji. 2000, Manajemen Bisnis. Jakarta: PT. Rineka Cipta.

Assael H (1998), Consumer Behavior and Marketing Action, Cincinnati, OH: Southwestern College Publishing.

Bain \& Co. (2005), “The new rules of luxury”, Financial Times, 18 May, available at: www.bain. com/publications/articles/luxury-goods-worldwide-market-studydecember-2014.aspx (accessed 25 February 2015).

Basu, Swastha, dan Irawan, 2001, Manajemen Pemasaran Modern, Liberty. Yogyakarta.

Bearden, W.O., Netemeyer, R.G., Teel, J.E. (1989), Measurement of consumer susceptibility to interpersonal influence. Journal of Consumer Research, Vol. 15, No. 4, pp. 473-481.

Belk, R. (1988), Possessions and self. New York: Wiley Online Library.

Berthon, P., Pitt, L., Parent, M. dan Berthon, J.P. (2009), "Aesthetics and ephemerality”, California Management Review, Vol. 52 No. 1, pp. 45-66.

Bian, Q. and Forsythe, S. (2012), "Purchase intention for luxury brands: a cross cultural comparison", Journal of Business Research, Vol. 65, No. 10, pp. 1443 1451.

Butcher, K., Sparks, B., O'Callaghan, F. (2002), Effect of social influence on repurchase intentions. Journal of Services Marketing, Vol. 16, No. 6, pp. 503514.

Chang, L. Y., Lee. Y. J., Chien. C. L., Huang. C. L. dan Chen. C. Y, (2010), The Influence of Consumer's Emotional Response and Social Norm on Repurchase Intention: A Case of Cigarette Repurchase in Taiwan. The Journal of International Management Studies, Vol. 5, No. 2.

Choo, H.J., Moon, H., Kim, H. and Yoon, N. (2012), "Luxury customer value", Journal of Fashion Marketing and Management: An International Journal, Vol. 16 No. 1, pp. 81-101.

Doss, F. dan Robinson, T. (2013), "Luxury perceptions: luxury brand vs counterfeit for young US female consumers", Journal of Fashion Marketing and Management: An International Journal, Vol. 17 No. 4, pp. 424-439. 


\section{E-Jurnal Ekonomi dan Bisnis Universitas Udayana 7.6 (2018): 1565-1588}

Engel, J., Blackwell, R., Miniard, P. (1986), Consumer Behavior. Chicago: CBS Publishing Company.

Engel, Blackwell, Miniard. (2001), Consumer Behavior 9th Edition. Ohio: South Western.

Fang, Y.H., Chiu, C.M., Wang, E.T. (2011), Understanding customers' satisfaction and repurchase intentions: An integration of IS success model, trust, and justice. Internet Research, Vol. 21, No. 4, pp. 479-503.

Goh, See Kwong., Jiang, Hak, Tee. (2016), Determinants of Smartphone Repeat Purchase Intention among Malaysians : A Moderation Role of Social Influence and a Mediating Effect of Consumer Satisfaction. International Review of Management and Marketing, Vol. 6, No. 4, pp. 993-1004.

Gounaris, S. and Stathakopoulos, V. (2004), "Antecedents and consequences of brand loyalty: an empirical study", Journal of Brand Management, Vol. 11, No. 4, pp. 283-306.

Gulati, R. (1995), "Does familiarity breed trust? The implications of repeated ties for contractual choice in alliance", Academy of Management Journal, Vol. 38, No. 1 , pp. 85-112.

Huang, M.H., Yu, S. (1999), Are consumers inherently or situationally brand loyal?-A set intercorrelation account for conscious brand loyalty and nonconscious inertia. Psychology and Marketing, Vol. 16, No. 6, pp. 523-544.

Hung, K.P., Chen, A.H., Peng, N., Hackley, C., Tiwsakul, R.A., Chou, C.L. (2011), Antecedents of luxury brand purchase intention. Journal of Product and Brand Management, Vol. 20, No. 6, pp. 457-467.

Hellier, P.K., Geursen, G.M., Carr, R.A. and Rickard, J.A. (2003), "Customer Repurchase Intention. A General Structural Equation Model”, European Journal of Marketing, Vol. 37, No. 11/12, pp. 1762-1800.

Hicks, J.M., Page Jr, T.J., Behe, B.K., Dennis, J.H., Fernandez, R. and Thomas. (2005), "Delighted Consumers Buy Again", Journal of Consumer Satisfaction, Dissatisfaction and Complaining Behaviour, Vol. 18, pp. 94-104.

Jones, M.A., Reynolds, K.E., Mothersbaugh, D.L., Beatty, S.E. (2007), The positive and negative effects of switching costs on relational outcomes. Journal of Service Research, Vol. 9, No. 4, pp. 335-355. 


\section{Claudia Lorenzia Core, dan Ni Wayan Sri Suprapti. Niat Konsumen Membeli...}

Kotler, P., \& Armstrong, G. (2007), Principles of Marketing (12th edition). Boston: Pearson Education.

Keller, K.L. (2003), "Brand synthesis: the multidimensionality of brand knowledge", Journal of Consumer Research, Vol. 29, No. 4, pp. 595-600.

Kotler dan Keller, (2007), Manajemen Pemasaran, Edisi 12, Jilid 1, PT.Indeks, Jakarta.

Kuo, Y.F., Hu, T.L., Yang, S.C. (2013), Effects of inertia and satisfaction in female online shoppers on repeat-purchase intention: The moderating roles of word-ofmouth and alternative attraction. Managing Service Quality: An International Journal, Vol. 23, No. 3, pp. 168-187.

Lee, H., Choi, S.Y., Kang, Y.S. (2009), Formation of e-satisfaction and repurchase intention: Moderating roles of computer self-efficacy and computer anxiety. Expert Systems with Applications, Vol. 36, No. 4, pp. 7848-7859.

Lee, M. and Cunningham, L.F. (2001), “A cost/benefit approach to understanding service loyalty", Journal of Services Marketing, Vol. 15, No. 2, pp. 113-30.

Lee, Richard dan Neale, Larry. (2012), Interactions and consequences of inertia and switching costs. Journal of Services Marketing, Vo. 26, No. 5, pp. 365-374

Lee, G.G. and Lin, H.F. (2005), "Customer perceptions of e-service quality in online shopping", International Journal of Retail and Distribution Management, Vol. 33. No. 2/3, pp. 161-176.

Li, G., Li, G., Kambele, Z. (2012), Luxury fashion brand consumers in China: Perceived value, fashion lifestyle, and willingness to pay. Journal of Business Research, Vol. 65, No. 10, pp. 1516-1522.

Li, N., Robson, A., Coates, N. (2013), Chinese consumers' purchasing: Impact of value and affect. Journal of Fashion Marketing and Management, Vol. 17, No. 4, pp. 486-508.

Ling C., Hwang W. and Salvendy G. (2006), Diversified users' satisfaction with advanced mobile phone features, Universal Access in the Information Society, Vol. 5, No. 2, pp. 239-249.

Liu, T., Wu, L.W., Hung, C. (2007), The effects of inertia and switching barriers on satisfaction-retention relationship: A case of financial service industries. Journal of Management, Vol. 24, No. 6, pp. 671-687. 


\section{E-Jurnal Ekonomi dan Bisnis Universitas Udayana 7.6 (2018): 1565-1588}

Nelson, M. R. \& McLeod L.E. (2005), Adolescents brand consciousness and product placement: Awareness, liking and perceived effects on self and others. International Journal of Consumer Studies, Vol. 25, No. 1, pp. 1-13.

Oliver, R.L. (1999), Whence consumer loyalty? The Journal of Marketing, Vol. 63, pp. 33-44.

Pappas, I.O., Pateli A.G., Giannakos, M.N., Chrissikopoulos, V. (2014), Moderating effects of online shopping experience on customer satisfaction and repurchase intentions. International Journal of Retail and Distribution Management, Vol. 42, No. 3, 187-204.

Penz, E., Stottinger, B. (2005), Forget the "real" thing : take the copy! An explanatory model for the volitional purchase of counterfeit products. Advances in Consumer Research, Vol. 32, pp. 568-575.

Pitt, L., Berthon, P., Parent, M., Berthon, J. (2009), Aesthetics and Ephemerality: Observing and Preserving the Luxury Brand. Boston: Harvard Business School Publishing, Vol. 52, No. 1, pp. 45-66.

Rashotte, L. (2007). Social Influences. Retrieved April 21, 2011 http://www.blackwellpublishing.com:443/sociology/docs/BEOS_S1413.pdf

Reichheld, F.F., Sasser, W.E.Jr. (1990), Quality gomes to services. Harvard Business Review, Vol. 3, No. 4, pp. 106.

Sánchez-García, I., Pieters, R., Zeelenberg, M., Bigné, E. (2012), When satisfied consumers do not return: Variety seeking's effect on shortand long-term intentions. Psychology and Marketing, Vol. 29, No. 1, pp. 15-24.

Solomon, M.R. (2007), Consumer Behavior: Buying, Having, and Being, 7th ed., Paramount Publishing, Boston, MA.

Smith, J.B. and Colgate, M. (2007), "Customer value creation: a practical framework", Journal of Marketing Theory and Practice, Vol. 15 No. 1, pp. 723.

Smith, R., Deppa, B. (2009), Two dimensions of attribute importance. Journal of Consumer Marketing, Vol. 26, No. 1, pp. 28-38.

Sweeney, J.C., Soutar, G.N. (2001), Consumer perceived value: The development of a multiple item scale. Journal of Retailing, Vol. 77, No. 2, pp. 203-220. 


\section{Claudia Lorenzia Core, dan Ni Wayan Sri Suprapti. Niat Konsumen Membeli...}

Tjiptono, F. (2001), Kualitas Jasa: Pengukuran, Keterbatasan dan Implikasi Manajerial, Majalah Manajemen Usahawan Indonesia. Jakarta

Tom, G., Barnett, T., Lew, W., Selmants, J. (1987), Cueing the consumer: The role of salient cues in consumer perception. Journal of Consumer Marketing, Vol. 4, No. 2, pp. 23-27.

Tsai, S.P. (2005), Utility, cultural symbolism and emotion: A comprehensive model of brand purchase value. International Journal of Research in Marketing, Vol. 22, No. 3, pp. 277-291.

Tynan, C., McKechnie, S. and Chhuon, C. (2010), "Co-creating value for luxury brands", Journal of Business Research, Vol. 63 No. 11, pp. 1156-1163.

Wang, F., Zhang, H., Zang, H., Ouyang, M. (2005), Purchasing pirated software: An initial examination of Chinese consumers. Journal of Consumer Marketing, Vol. 22, No. 6, pp. 340-351.

White, L., Yanamandram, V. (2007), A model of customer retention of dissatisfied business services customers. Managing Service Quality: An International Journal, Vol. 17, No. 3, pp. 298-316.

Ye, G. (2005), "The locus effect on inertia equity", Journal of Product \& Brand Management, Vol. 14, No. 3, pp. 206-10.

Zboja, J.J., Voorhees, C.M. (2006), The impact of brand trust and satisfaction on retailer repurchase intentions. Journal of Services Marketing, Vol. 20, No. 6, pp. 381-390.

Zeelenberg, M. and Pieters, R. (2004), "Beyond valence in customer dissatisfaction: a review and new findings on behavioral responses to regret and disappointment in failed services", Journal of Business Research, Vol. 57, No. 4, pp. 445-55.

Zeithaml,Valarie A and Bitner, M.J. (2003), Service Marketing. Tata McGraw-Hill.

Zeng, Fue. Hu, Zuohao. Chen, Rong dan Yang,Zhilin. (2009), "Determinants of online service satisfaction and their impacts on behavioural intention". Total Quality Management. Vol. 20, No. 9, 953-969.

Zhang, Z., Li, Y., Gong, C., Wu, H. (2002), Casual wear product attributes: A Chinese consumers' perspective. Journal of Fashion Marketing and Management: An International Journal, Vol. 6, No. 1, pp. 53-62. 